\title{
MORPHOMETRIC STUDY OF MENISC OF THE KNEE JOINT
}

\author{
ESTUDIO MORFOMÉTRICO DE LOS MENISCOS DE LA ARTICULACIÓN DE LA RODILLA
}

\author{
Katiúcia Samara da Silva Almeida; Silvia Regina Arruda de Moraes; Tetsuo Tashiro; Elizabeth da Silveira Neves; \\ Ana Elisa Toscano; Roseanne Maria Rocha de Abreu
}

\begin{abstract}
ALMEIDA, S. K S.; DE MORAES, A. S. R.; TASHIRO, T.; NEVES, S. E.; TOSCANO, A. E. \& DE ABREU, R. R. M. Morphometric study of menisc of the knee joint. Int. J. Morphol., 22(3):181-184, 2004.

SUMMARY: We analyzed the meniscus morphometrics aspects of the knee joint as such: extern circunference tickness, the breadth, the area and distance between anterior and posterior horns, the tibial plateau correspondent area, meniscus area/tibial plateau report, check the Wrisberg's ligament length. There were analyzed 44 meniscus of the 22 knees adults men corpses. The tickness and breadth morphometrics variables were evaluated in three different points: anterior medium and posterior third part and compared values between medial and lateral compartments. In the medial meniscus weren't meaningful difference between anterior, medium and posterior third part thickness, while medium third part lateral meniscus showed such as larger thickness. When analyzed the breadth, watched the medial meniscus posterior third part were the larger area, while the lateral meniscus there weren't neither meaningful difference between three analyzed points. The distance between anterior and posterior horns such as the meniscus medial area, it showed meaningfully lager than lateral meniscus. The tibial plateau area didn't showed statistics difference between lateral and medial compartments. The morphometrics meniscus results demonstrated relation with clinics data. The medial meniscus is more broad and it occupied the area of the higher tibial plateau what justify the higher lesions incidence that attack this meniscus. Like wise, the measurement values of third part confirmed the frequency higher of break in this region.
\end{abstract}

KEY WORDS: 1. Morphometry; 2. Knee; 3. Meniscus.

\section{INTRODUCTION}

The menisci are considered main elements for a perfect articulation among the articular osseous surfaces (Testut \& Latarjet, 1977; Olmedillo et al., 1990, Xavier et al., 1998), performing mechanical functions, such as supporting the corporal weight, shock absorption, stabilization and rotational facilitation (Whiting \& Zernicke, 2001). The function of stabilization in every plans, but mainly, the rotational is one of the most important and it is directly related to the meniscal traumatisms (Xavier et al.). There are marked differences in the contour and insertion between the lateral and the medial menisci which are important in relation to the injury mechanisms (Smillie, 1975).

Variations of form and in particular of thickness and width of menisci can determine the possibility and the kind of injury. However, the data related to the morphometric parameters of these structures are scarce. Because of it, the aim of our work was to determine the thickness of outer circumference and the width of menisci, the distance between anterior and posterior cornua and the relation between the area of menisci and the area of corresponding tibial plates.

\section{MATERIAL AND METHOD}

For this study 44 menisci of 22 knees (02 bilateral and 18 unilateral) of corpse treated with a watery solution of formaldehyde of male sex individuals, in $25-35$ age range were used, the corpses belong to anatomy subject of the Departamento de Anatomia da Universidade Federal de Pernambuco. All menisci that showed any structural change which prevent its morphometric analysis such as injuries or advanced degenerative changes, were excluded.

To measure the thickness of outer circumference of menisci, firstly was determined its length. For this, a line was positioned from the apex of anterior cornu to the apex of posterior cornu of meniscus. The length of the line was measured with a analogical pachymeter (Vernier Calpers $0.02 \mathrm{~mm}$ ). The values were registered and divided by four (25\%), establishing three points on the line: one anterior, one medium and one posterior. After, this line was positioned again on the outer circumference of meniscus, enabling that the three points were transferred for it. From each point, and using the outer measurement of pachymeter, the length of menisci was measured. The width of menisci was determined

Departamento de Anatomia da Universidade Federal de Pernambuco, Brazil. 
using the same points of the thickness. Using a pair of set squares, from each point, one line was drawn from the peripheral margin to the central margin of meniscus, and using the inner measurement of pachymeter, the width was measured (Fig.1).

To calculate the area of menisci and tibial plates, the adopted procedure was the measurement by comparison, draws of the contour of menisci and tibial plates were obtained using a paper of medium filtration (Vetec). After, the weight of this draws was measured by a digital scale Denver Instrument Company, model AA-160. Circumferences with different radius were drawn on filter paper, then, its area was calculated by the mathematical formula: $\mathrm{A}=\pi \times \mathrm{r}^{2}$. The weight of these circumferences was measured by a digital scale, and after, a mathematical relation was established between the area of the circumference and its weight, enabling to calculate the area of each meniscus by its weight previously determined. At the end, was measured the distance between the apex of anterior and posterior cornua of lateral and medial menisci. The data were statistically analyzed by the T test of Student for independent samples, considering the level of significance of 0,05 $(\alpha=0,05)$.

\section{RESULTS}

Related to the thickness of outer circumference of meniscus, a difference statistically significant was not observed $(\mathrm{p}>0,05)$ among the anterior, medium and posterior thirds of medial meniscus. However, in the lateral meniscus, the medium third was the thickest part $(\mathrm{p}<0,05)$ (Table I). Comparing the average values of medial meniscus with the values of lateral meniscus, was observed that in the anterior and posterior thirds, the medial meniscus was significantly more thick $(\mathrm{p}<0,05)$ relating to the lateral meniscus. (Table I). The individual analysis of each meniscus showed that the posterior third was the widest part of the medial meniscus $\mathrm{p}<0,05$ ); while in the lateral meniscus was not observed any difference statistically significant $(\mathrm{p}>0,05)$ among the three examined points (Table II). In the medium third, there was not difference statistically significant when comparing the lateral and the medial menisci $(p>0,05)$. However the anterior and the posterior thirds showed a difference statistically significant between the two groups. The relation area of meniscus / area of tibial plate showed a percentage average value of $54,70 \pm 7,32 \%$ in the medial part and $48,67 \pm 4,43 \%$ in the lateral part $(\mathrm{p}<0,01)$. The distance between the anterior and posterior cornua of medial meniscus $(29,70 \pm 4,12 \mathrm{~mm})$ was significantly higher than $(\mathrm{p}<0,05)$ lateral meniscus $(12,71$ $\pm 1,84 \mathrm{~mm})$.

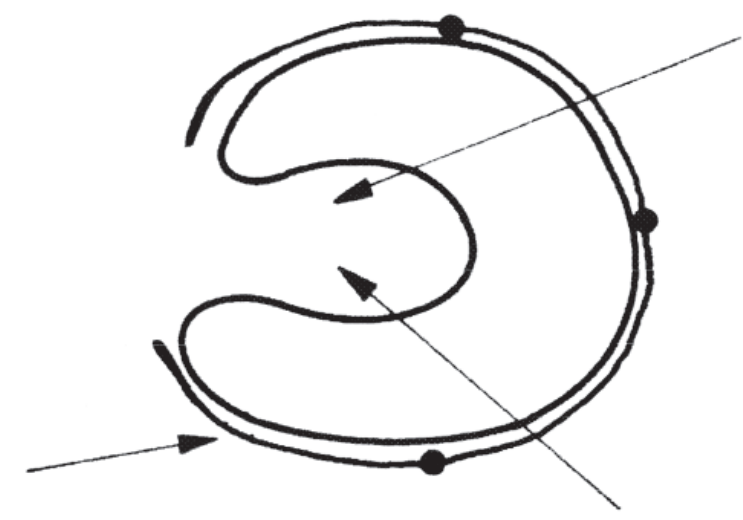

Fig. 1. Diagram representing the three points of morphometric analysis of menisci in the anterior, medium and posterior thirds.

Table I. Thickness of medial and lateral menisci (mm).

\begin{tabular}{cccc}
\hline Medial menisci & Anterior third & Medium third & Posterior third \\
& $5,92 \pm 1,37^{*}$ & $5,31 \pm 1,06$ & $5,91 \pm 1,13^{*}$ \\
Lateral menisci & $3,71 \pm 1,15$ & $6,10 \pm 1,04 *$ & $5,29 \pm 0,78$ \\
\hline
\end{tabular}

Values are means $\pm S E, n=44$. Statistical significance (t- test) $* \mathrm{p}<0,05$.

Table II.Width of medial and lateral menisci (mm).

\begin{tabular}{lccc}
\hline Medial menisci & Anterior third & Medium third & Posterior third \\
& $9,02 \pm 1,59$ & $12,16 \pm 2,58$ & $17,37 \pm 2,22 *$ \\
Lateral menisci & $11,86 \pm 1,81 *$ & $11,97 \pm 2,56$ & $11,44 \pm 1,07$ \\
\hline \multicolumn{2}{l}{ Values are means $\pm \mathrm{SE}, \mathrm{n}=44$. Statistical significance (t- test) $* \mathrm{p}<0,05}$.
\end{tabular}

\section{DISCUSSION}

The data referring to the dimensions of semilunar cartilages are varied. Testut \& Latarjet in a more generalized description of the morphometry of menisci, mention that the average thickness of outer circumference is $8 \mathrm{~mm}$ for the lateral meniscus and $6 \mathrm{~mm}$ for the medial meniscus, and that the average width of menisci is $10-12 \mathrm{~mm}$. Motta Filho et al. (1999), on the other hand, described in their studies an average thickness of $4-5 \mathrm{~mm}$ and an average width of approximately $12 \mathrm{~mm}$ for the lateral meniscus.

According to Cailliet (1976), the lateral meniscus shows an average width of $12-13 \mathrm{~mm}$, while the medial meniscus has an average width of $10 \mathrm{~mm}$. Hayashi et al. (1988), talking about the necessity of to reduce substantially the thickness and the width of discoid meniscus during the surgical procedure, describes that the normal menisci show thickness and width of $6-8 \mathrm{~mm}$ and $12-13 \mathrm{~mm}$, respectively.

In this study, the morphometric variables thickness and width of menisci, were analized in three different points: 
anterior, medium and posterior thirds. Relating to the thickness, the medium third of medial meniscus was the less $(5,31 \mathrm{~mm})$ followed by the posterior $(5,91 \mathrm{~mm})$ and anterior $(5,92 \mathrm{~mm})$ thirds, showing an average value of $5,71 \mathrm{~mm}$. To corroborate our results, Rico \& Ayala (1997), in an arthroscopic revision which aim was to determine the topographic location of meniscal ruptures, observed that the medium third of medial meniscus is the local more frequently injured, followed by the posterior third.

The lateral meniscus showed a significant difference among the anterior $(3,57 \mathrm{~mm})$, medium $6,10 \mathrm{~mm})$ and posterior $(5,92 \mathrm{~mm})$ thirds, with the medium as the thickest point of the meniscus. According to Figueroa et al. (1999) the lateral meniscus is liable to higher variations in its general configuration than the medial meniscus, appearing frequently wider in the body. However, in this study it was not observed any difference statistically significant among the width of anterior, medium and posterior thirds of lateral meniscus. On the other hand, the medial meniscus is described by Didio (2002), showing a posterior cornu quite wide and an anterior extremity sharp and thin. This description is according to the results of our statistical study which showed the medial meniscus wider on the posterior third, followed by the medium third, and in the end by the anterior third.

According to Smillie the lateral meniscus shows a width higher and more uniform than the medial meniscus. However, Testut \& Latarjet and Didio, mention that is common the medial meniscus be a little wider than the lateral meniscus. In this study, we found an average width for the medial meniscus of $12,85 \mathrm{~mm}$ and for the lateral meniscus of $11,76 \mathrm{~mm}$. According to Smillie the morphological differences of menisci, in particular, in the thickness and width can determine not only the possibility of an injury, but also the location and the kind of injury. This author also suggests that the narrow meniscus is less prone to ruptures than the wide. This supposition is justified because the narrow meniscus is liable to a less action of femural condyle. A higher evidence of this context is suggested by the rarity of injuries of the anterior third of medial menisci, as related by Alonso et al. (1996) and Rico \& Ayala (1997). In our study, the posterior third of medial meniscus, was the widest part, while the anterior third was the narrowest part of meniscus.

According to Cohen et al. (1993), the menisci cover from $1 / 2$ to $2 / 3$ of articular surface of corresponding tibial plate, with the lateral meniscus covering an area higher than the medial meniscus. According to Smillie and Farias Filho et al. (1985), the lateral meniscus cover a higher area of the tibial plate, due to its semicircular format, been near the insertions of its cornua. Actually, in this study we established that the distance between the anterior and posterior cornua of lateral meniscus is significant less than the medial meniscus, giving an aspect in which the lateral meniscus shows the form of a ring almost complete. This high proximity between the insertions of its cornua, would be one of the reasons for the lateral meniscus be less prone to lacerations (Kapandji, 1998; Miranda, 2000). After analyzed the relation meniscus area/ tibial plate area, we verified that the medial meniscus covers an area of tibial plate significant higher $(54,71 \%)$ than the lateral meniscus $(48,67 \%)$ which justifies the higher incidence of injuries of medial meniscus because it suffers a higher action of femoral condyle. The results of this study showed that there is an important relation between the morphometric data of menisci and the data found in clinic, which would explain the incidence of injuries in specific points of each meniscus.

\footnotetext{
ALMEIDA, S. K S.; DE MORAES, A. S. R.; TASHIRO, T.; NEVES, S. E.; DA SILVA, M. A. E. T. \& DE ABREU, R. R. M. Estudio morfométrico de los meniscos de la articulación de la rodilla. Int. J. Morphol., 22(3):181-184 2004.

RESUMEN: Investigamos los aspectos morfométricos de los meniscos de la articulación de la rodilla tales como: grosor de la circunferencia externa y el ancho de los meniscos, relación área del menisco/área del platillo de la tibia y la distancia entre los cuernos posterior y anterior de cada menisco. Fueron analizados 44 meniscos de 22 rodillas de cadáveres humanos, adultos, de sexo masculino. Las variables morfométricas ancho y grosor fueron evaluadas en tres puntos distintos: tercio anterior, tercio medio y tercio posterior, $\mathrm{y}$ sus valores comparados entre los compartimientos medial y lateral. En el menisco medial no hubo diferencia significativa, en lo que se refiere al grosor, entre los tercios anterior, medio y posterior, mientras que en el menisco lateral, el tercio medio se mostró como sitio de mayor grosor. En cuanto al ancho, se observó que el tercio posterior del menisco medial fue estadísticamente el sitio más ancho del menisco, mientras que en el menisco lateral no hubo ninguna diferencia significativa entre los tres puntos analizados. La relación área del menisco/área del platillo de la tibia y la distancia entre los cuernos anterior y posterior fueron mayores en el compartimiento medial. Los resultados morfométricos de los meniscos demostraron relación con los datos clínicos. El menisco medial se mostró más ancho y ocupando una área de cobertura del platillo de la tibia más grande, lo que justifica la mayor incidencia de lesiones que afectan ese menisco. De la misma manera, los valores de medición en su tercio medio, confirman la mayor frecuencia de rupturas en esa región.
}

PALABRAS CLAVE: 1. Morfometría; 2. Rodilla; 3. Menisco. 


\section{REFERENCES}

Cailliet, R. M. D. Síndromes Dolorosas. Joelho: dor e incapacidade. Río de Janeiro, Manole, 1976.

Cohen, M. J.; Abdalla, R. J.; Barreto, F. A. Q. M.; Bouchabki, E. T.; Oliveira, E. C. \& Ejnisman, B. Estudo da vascularização do menisco humano. Rev. Bras. Ortop., 28(5):263-72, 1993.

Didio, L. J. A. Tratado de Anatomia Aplicada. 2. ed. São Paulo, Atheneu, 2002.

Farias Filho, O. C.; Lyrio Mello, R.S.; Souza, D.C. de \& Paz Júnior, A. C. da. Menisco discóide: estudo retrospectivo. Rev. Bras. Ortop., 20(3):106-10, 1985.

Figueroa, M.; Ríos, A. L. de L.\& Narváez, C. Menisco discoide interno: presentación de un caso y revisión de la literatura. Rev. Colom. Ortop. Traumat., 3(2):155-8, 1999.

Hayashi, L. K.; Yamaga, H.; Ida, K. \& Miura, T. Arthroscopic meniscectomy for discoid lateral meniscus in children. J. Bone Joint Surgery, 70A(10):1495-500, 1988.

Kapandji, A. I. Fisiología Articular. 5. ed. Paris, Panamericana, 1998.

Miranda, E. Bases de Anatomia e Cinesiologia. 1. ed. Rio de Janeiro, Sprint, 2000.

Motta Filho, L. A. J.; Motta, L. A. J. \& Mota Filho, G. R. Menisco lateral discóide: correlação anátomo-clínica. Rev. Bras. Ortop., 34(8):457-60, 1999.

Olmedillo, O. G.; Goatache, G. \& Palazzi, F. F. Menisco discoide. Rev. Soc. Med. Hosp. San Juan de Dios, 11(11):25-8, 1990.

Rico, E. G. C.; \& Ayala, C. E. A. Localización de las rupturas meniscales en nuestro medio. Rev. Mex. Ortop. Traumatol., 11(1):10-13, 1997.

Smillie, I. S. Injuries of the knee Joint. 4. ed. London, Living Stone, 1975.

Testut, L. \& Latarjet, A. Tratado de Anatomía Humana. 10. ed. Barcelona, Salvat, 1975.

Whiting, C.W. \& Zernicke, R.F. Biomecânica da lesão musculoesquelética. 1.ed. Rio de Janeiro, Guanabara Koogan, 2001.
Xavier, S. R. H.; Júnior, A. G. P.; Filho, T. E. P. B. Lesões Menisco- Ligamentares do Joelho. In: Amatutuzzi, M. M.; Hernandez, A. J.; Motta, F. da. Ortopedia e Trumatologia: Princípios e Prática. 2. ed. Porto Alegre, Artmed, 1998.

Correspondence to:

Prof. Dra. Silvia Regina Arruda de Moraes

Departamento de Anatomia

Universidade Federal de Pernambuco

CEP 50070-080

Rua Capitão Rui Lucena, 160/501

Boa Vista - PE

BRASIL

email:Silvia@ufpe.br

Received: 02-04-2004

Accepted: 26-06-2004 